\title{
BIOTECHNOLOGICAL TOOLS TO IMPROVE BIOREMEDIATION OF PHENOL BY Acinetobacter sp. RTE1.4
}

Cintia E. Paisio, Melina A. Talano, Paola S. González, Cynthia MagallanesNoguera, Marcela Kurina-Sanz \& Elizabeth Agostini

To cite this article: Cintia E. Paisio, Melina A. Talano, Paola S. González, Cynthia MagallanesNoguera, Marcela Kurina-Sanz \& Elizabeth Agostini (2016): BIOTECHNOLOGICAL TOOLS TO IMPROVE BIOREMEDIATION OF PHENOL BY Acinetobacter sp. RTE1.4, Environmental Technology, DOI: $10.1080 / 09593330.2016 .1150352$

To link to this article: http://dx.doi.org/10.1080/09593330.2016.1150352

Accepted author version posted online: 07 Feb 2016.

Submit your article to this journal $₫$

山 Article views: 2

Q View related articles $₫$

View Crossmark data 5 
Publisher: Taylor \& Francis

Journal: Environmental Technology

DOI: $10.1080 / 09593330.2016 .1150352$

BIOTECHNOLOGICAL TOOLS TO IMPROVE BIOREMEDIATION OF PHENOL BY Acinetobacter Sp. RTE1.4

Cintia E. Paisio ${ }^{a *}$, Melina A. Talano ${ }^{a}$, Paola S. González ${ }^{a}$, Cynthia Magallanes-Noguera ${ }^{b}$, Marcela Kurina-Sanz ${ }^{b}$, Elizabeth Agostini ${ }^{\mathrm{a}}$

a Departamento de Biología Molecular, FCEFQyN, Universidad Nacional de Río Cuarto, 5800 Río Cuarto, Córdoba, Argentina

bINTEQUI-CONICET, Facultad de Química Bioquímica y Farmacia, Universidad Nacional de San Luis. Chacabuco y Pedernera, 5700, San Luis, Argentina

*Corresponding author

Departamento de Biología Molecular, FCEFQyN, UNRC.

Ruta 36 Km 601. CP 5800 Río Cuarto (Cba) Argentina.

Telephone: 54-358-4676537; Fax: 54-358-4676232; E-mail: cpaisio@exa.unrc.edu.ar 


\section{Abstract}

The use of native bacteria is a useful strategy to decontaminate industrial effluents as well as the environment. Acinetobacter sp. RTE1.4 was previously isolated from polluted environments and constitutes a promising alternative for this purpose due to its capability to remove phenol from synthetic solutions and industrial effluents

In this work, this strain was identified at species-level as $A$. tandoii RTE1.4. Phenol degradation pathway was studied and some reaction intermediates were detected, confirming that this strain degraded phenol through orthocleavage of the aromatic ring. Phenol removal assays were carried out in a stirred tank bioreactor and a complete degradation of the contaminant was achieved after only $7 \mathrm{~h}$, at an aeration rate of $3 \mathrm{Vvm}$ and at agitation of $600 \mathrm{rpm}$. Moreover, this bacterium was immobilized into calcium alginate beads and an increase in phenol biodegradation respect to free cells was observed. The immobilized cells were reused for four consecutive cycles and stored at $4{ }^{\circ} \mathrm{C}$ for 9 months, during which phenol removal efficiency was maintained. Post removal solutions were evaluated by Microtox® test, showing a toxicity reduction after bacterial treatment. These findings demonstrated that A. tandoii RTE1.4 might be considered as a useful biotechnological tool for an efficient treatment of different solutions contaminated with phenol in bioreactors, either using free or immobilized cells

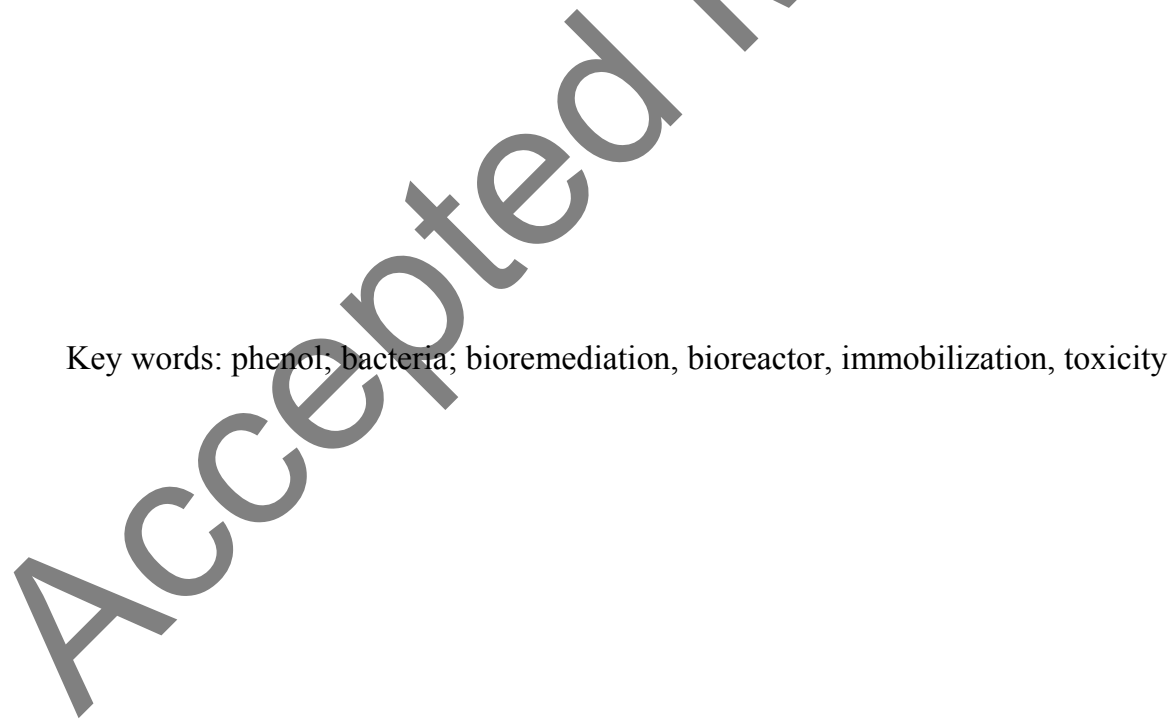




\section{INTRODUCTION}

Phenol is one of the pollutants most frequently found in the environment and is considered as a priority pollutant because of its adverse effects on animal and human health, widespread diffusion and persistence in the environment.

Industrial phenol production is estimated to be over three million tons per year, being used mostly in petrochemical industry, synthesis of resins, pharmaceuticals, perfumes, as well as intermediate in the preparation of other chemicals (e.g., plastics, drugs, explosives, pesticides and detergents), solvents or lubricating oils [1]. Due to their high production and usage, phenol arises as wastes or by-products of the above mentioned industries.

With the aim of protecting human and animal health, the United States Environmental Protection Agency [2], has established limit concentrations for phenol in drinking-water less than 3.5 mg/L. In Argentina, the law of Hazardous wastes (Law 24,051, Annex II), established a guide level of $1 \mu \mathrm{g} / \mathrm{L}$ for protecting aquatic life in fresh surface water, and $2 \mu \mathrm{g} / \mathrm{L}$ for water source for human consumption [3]. However, higher concentrations than those mentioned were frequently found in contaminated environments. Therefore, the removal of such compound from water and soils is of relevant significance.

As a consequence, various physicochemical treatments such as distillation, liquid-liquid extraction with different solvents, adsorption, membrane pervaporation and membrane-solvent extraction have been proposed to remediate phenol polluted sites [4]. However, these treatments are complex, expensive and, sometimes, they produced more toxic compounds. Thus, it has become necessary to look for environmentally friendly technologies, such as biological methods, which are safer and least disruptive treatments.

At present, there are a variety of technologies developed for the remediation of contaminated water or industrial effluents, involving the use of bacteria in batch and/or continuous processes in bioreactors, using cell-free cultures or immobilized cells in various matrices [5,6]. The aims of this work were to establish the identity at specie level of a bacterium previously isolated, characterized and named as Acinetobacter sp. RTE1.4 strain by our research group and to study its performance on phenol degradation process in a stirred tank reactor. In addition, we were interested in determining if its immobilization into calcium alginate beads could contribute to enhance phenol removal. Moreover, a bioassay for the determination of potential toxic effects of treated solutions was also applied and evaluated.

\section{MATERIALS AND METHODS}

\subsection{Microorganism and culture conditions}

In this work, Acinetobacter sp. RTE1.4, isolated from an effluent derived from a chemical industry and previously characterized in detail was used [7]. Bacterium was routinely grown on TY agar medium [(g/L): 5 tryptone; 
3 yeast extract; $0.65 \mathrm{CaCl}_{2} ; 13$ agar] and kept at $4^{\circ} \mathrm{C}$. For the different experiments described below, inocula were prepared by growing the strain in TY liquid medium.

\subsection{Identification at the species-level}

Identification of Acinetobacter sp. RTE1.4 strain at the species level was initially based on analysis of the sequence of the housekeeping gene recombinase A (recA). For that, a bacterial culture was incubated in TY medium at $28 \pm 2{ }^{\circ} \mathrm{C}$ during $12 \mathrm{~h}$ and bacterial genomic DNA was obtained using DNA purification kit (Wizard-Promega) according to protocols supplied by the manufacturer. This DNA preparation was used as a template for recA gene amplification by PCR using the primer pair rA1/rA2 described previously by Nowak and Kur [8]. The sequences of these primers were: rA1 (5'-CCTGAATCTTCTGGTAAAAC-3') and rA2 (5'-GTTTCTGGGCTGCCAAACATTAC3').

Amplification reactions were carried out in $25 \mu 1$ final volumes containing the following reagents: $20 \mathrm{mM}$ Tris$\mathrm{ClH}(\mathrm{pH} 8.4) / 50 \mathrm{mM} \mathrm{KCl}$ buffer, $1.5 \mathrm{mM} \mathrm{MgCl}_{2}$, each triphosphate deoxynucleotide at a concentration of $0.2 \mathrm{mM}, 0.3$ $\mu \mathrm{M}$ of each primer, $5.5 \mu \mathrm{g}$ of template DNA and 2.5 U Taq DNA polymerase (Invitrogen). The PCR conditions used were 3 min of denaturation at $94{ }^{\circ} \mathrm{C}, 35$ cycles of 1 min of denaturation at $94{ }^{\circ} \mathrm{C}, 1$ min of primer annealing at $45^{\circ} \mathrm{C}$ and 2 min of extension at $72^{\circ} \mathrm{C}$, followed by a final step at $72^{\circ} \mathrm{C}$ for $5 \mathrm{~min}$. PCR reactions were performed in an iCycler (Bio-Rad) thermocycler. Aliquots $(10 \mu \mathrm{l})$ of the PCR products were analyzed by electrophoresis on a $1 \%$ agarose gel containing $0.5 \mu \mathrm{g} / \mathrm{mL}$ ethidium bromide using $100 \mathrm{bp}$ size marker (Invitrogen). The PCR products were purified with DNA PuriPrep-GP kit (Highway) according to the manufacturer's recommendations and submitted for sequencing to Instituto Nacional de Tecnología Agropecuaria (INTA, Castelar, Argentina). The obtained recA gene sequence was compared and identified using BLAST program [9] and deposited in GeneBank database under the following accession number JX258136.

A phylogenetic tree was constructed based on the recA gene sequences from different Acinetobacter species. For that, multiple alignments of different recA gene sequences downloaded from GenBank were performed using CLUSTAL-X software and the evolutionary distances were calculated by the Tamura-Nei model. For the phylogenetic tree construction the Neighbor-Joining method by MEGA4 software [10] was used and a bootstrap analysis of up to 1000 iterations were carried out.

In addition, matrix-assisted laser desorption/ionization time-of-flight mass spectrometry (MALDI-TOF MS) was used to improve identification, using a Bruker Daltonics equipment (Germany). Samples were prepared using cells from a single colony of a fresh overnight culture following the ethanol/formic acid extraction procedure recommended by the manufacturer (Bruker Daltonik, Bremen, Germany). The procedure was done following standard procedures [11]. MALDI-TOF MS measurements were made using an Microflex III instrument (Bruker Daltonik, Bremen, Germany) for the automatic acquisition of mass spectra according to the manufacturer's instructions. The peaks from the obtained mass spectra and their matching against the reference spectra of the integrated database was performed using MALDI Biotyper Software (Bruker Daltonics). Score values $\geq 2.0$ were considered appropriate for identification at species level [12].The results were analyzed using the software Microflex 3.1. These studies were carried out at the specialized Laboratory of Clinical Microbiology of Hospital Juan A. Fernández (Buenos Aires, Argentina). 


\subsection{Evaluation of intermediates of phenol metabolism}

For sample preparation, the bacterial strain grew in TY liquid medium until late exponential phase. Then, this culture was inoculated in $250 \mathrm{~mL}$ Erlenmeyer flasks $(10 \% \mathrm{~V} / \mathrm{V})$ containing $50 \mathrm{~mL}$ of liquid minimum medium (MM) [(g/L): $\left.2.8 \mathrm{Na}_{2} \mathrm{PO}_{4} \mathrm{H} ; 9.0 \mathrm{KPO}_{4} \mathrm{H}_{2} ; 2.5 \mathrm{NaCl} ; 1.0 \mathrm{NH} 4 \mathrm{Cl}\right]$ with phenol $200 \mathrm{mg} / \mathrm{L}$ as sole carbon source. The flasks were placed in a shaker at $100 \mathrm{rpm}$ at controlled temperature $\left(28^{\circ} \mathrm{C}\right)$ until phenol was completely removed. The culture was centrifuged at $12,000 \mathrm{~g}$ at $4{ }^{\circ} \mathrm{C}$ for $10 \mathrm{~min}$. Aliquots $(10 \mathrm{~mL})$ of supernatants were used to identify reaction intermediates. Samples were acidified to $\mathrm{pH} 2.5$ with $\mathrm{HCl} 0.5 \mathrm{~N}$, extracted with $20 \mathrm{~mL}$ of with ethyl acetate $(20 \mathrm{~mL} x$ 2), dried over anhydrous $\mathrm{Na}_{2} \mathrm{SO}_{4}$, filtered and evaporated under vacuum. Solids were resuspended in $1 \mathrm{~mL}$ of mobile phase, filtered through a $0.25 \mu \mathrm{m}$ nylon filter to remove cell debris. Samples were analyzed by HPLC (Section 2.7.1).

\subsection{Phenol biodegradation in a stirred tank bioreactor}

In order to maximize the removal efficiency of higher volumes of phenol by Acinetobacter sp. RTE1.4, the potential of this strain for phenol degradation under controlled agitation and aeration conditions was evaluated in a bioreactor. For that, a 5 L stirred tank bioreactor (BIOFLQ 2000, New Brunswick Scientific, U.S.A.) was used.

The bioreactor was operated in batch mode with an initial phenol concentration of $200 \mathrm{mg} / \mathrm{L}$ at $\mathrm{pH} 7$ and $28 \pm 2^{\circ} \mathrm{C}$ under different rotational speeds and airflow rates: 200, 400 and $600 \mathrm{rpm}$ and 1 and $3 \mathrm{vvm}$, respectively. The reactor vessel was carefully sterilized by autoclave prior all experiments, at $120^{\circ} \mathrm{C}, 1 \mathrm{~atm}$ for $30 \mathrm{~min}$. A volume of $2 \mathrm{~L}$ of $\mathrm{MM}$ was inoculated with $200 \mathrm{~mL}$ of an Acinetobacter sp. RTE1.4 culture, previously grown in TY medium without phenol, until late exponential phase of growth $\left(\mathrm{OD}_{620} \mathrm{~nm} 0.9 \pm 0.1\right.$ equivalent to $\left.2.2 \pm 0.87 \times 10^{11} \mathrm{CFU} / \mathrm{mL}\right)$. Non-inoculated controls were also assessed. Culture samples were withdrawn each two hours by quadruplicate and tested for biomass and residual phenol concentration (Sections 2.7.2 and 2.7.3).

2.5 Phenol biodegradation using immobilized cells

2.5.1 Entrapment of cells in calcium alginate

Acinetobacter sp. RTE1.4 was inoculated into $100 \mathrm{~mL}$ TY medium in $250 \mathrm{~mL}$ Erlenmeyers flasks, incubated at $28 \pm 2^{\circ} \mathrm{C}$ and agitated at $100 \mathrm{rpm}$ until optimum growth was achieved $\left(\mathrm{OD}_{620 \mathrm{~nm}} 0.9 \pm 0.1\right)$. Next, $10 \mathrm{ml}$ of this culture (cell content in terms of wet weight was equivalent to $0.6 \mathrm{~g}$ of cells) was added to $30 \mathrm{ml}$ of a $4 \% \mathrm{~W} / \mathrm{V}$ sterilized Na-alginate solution, obtaining final alginate concentration of $3 \%(\mathrm{~V} / \mathrm{V})$. These alginate-cell suspensions were extruded into a $0.2 \mathrm{M}$ $\mathrm{CaCl}_{2}$ solution to form beads with a diameter of approximately $3 \mathrm{~mm}$. This procedure was performed with continuous stirring. The beads were gelled for 20 min under stirring. Then, they were washed three times with sterile saline solution (SSS) and were maintained in the same solution. After 40-60 min, these beads were used for phenol degradation 
experiments and/or stored at $4{ }^{\circ} \mathrm{C}$. The immobilization procedure was performed under sterile conditions and all solutions were previously sterilized.

\subsubsection{Phenol degradation assays}

Phenol degradation assays, using Acinetobacter sp. RTE1.4 cells immobilized in calcium alginate beads were conducted in Erlenmeyer flasks $(100 \mathrm{~mL})$ containing $30 \mathrm{~mL}$ of MM without phosphates, supplemented with phenol concentrations between 200 and 2,500 mg/L. Each flask was inoculated with $24 \mathrm{~g}$ of beads.

In all experiments, controls were performed using the same medium inoculated with free cells $(10 \% \mathrm{~V} / \mathrm{V})$, previously grown in TY medium until late exponential phase $\left(\mathrm{OD}_{620 \mathrm{~nm}} 0.9 \pm 0.1\right)$. Abiotic controls consisting of the same culture medium inoculated with calcium alginate beads without bacterial cells were also performed.

The Erlenmeyer flasks containing immobilized bacteria, free cells or beads without bacterial biomass were incubated at $28 \pm 2{ }^{\circ} \mathrm{C}$. They were stirred at $100 \mathrm{rpm}$. Medium and beads samples were taken at different time intervals (each 3 or $10 \mathrm{~d}$ ) to evaluate phenol removal and bacterial biomass in order to analyze the possible losses of cells as a result of the broken beads.

All assays were performed three times by triplicate.

2.5.3 Reusability and stability during storage of immobilized cells

Repeated cycles of phenol (200 mg/L) biodegradation were carried out to establish the reusability of immobilized cells. After complete phenol degradation, the used medium was discarded and fresh medium containing the same phenol concentration was added to the flasks. The degradation processes were performed until the beads lost their degradation ability.

In order to evaluate the stability during storage, free and immobilized cells were stored at $4{ }^{\circ} \mathrm{C}$, and then the cells were tested for their phenoldegradation capability, at different time periods.

In both cases, phenol degradation assays were carried out as it was previously described in section 2.5.2.

\subsubsection{Biomass estimation}

Biomass was estimated through determination of protein content and viable cell number.

Protein content was assessed in beads, in the reaction medium of the beads and in the culture medium containing the free cells.

For protein determination in beads, the method described by Mollaei et al. [13] was used. One g of beads was sectioned into a number of pieces using a surgical knife, that were then incubated in $3 \mathrm{~mL}$ of sodium dodecyl sulphate (SDS) solution (10\%) during $2 \mathrm{~h}$ for protein extraction. After centrifugation, proteins were determined by Bradford method using bovine serum albumin as a standard [14]. To determine protein in the medium containing free cells as well as in reaction media of the beads, $2 \mathrm{~mL}$ of culture were centrifuged at 10,000 rpm and the pellet was suspended in $3.5 \mathrm{ml}$ of distilled water. Then, SDS solution was added to this solution as it was described before. 
In order to determine the viable cell number contained into the beads, the method described by Sossa Urrego et al. [15] was used. Ten alginate beads were rinsed twice with a sterile $0.9 \% \mathrm{NaCl}$ solution and resuspended in $250 \mu 1$ of sterilized $0.16 \mathrm{M}$ phosphate buffer, $\mathrm{pH}$ 7.4. The suspension was homogenized to achieve a complete dissolution of the alginate, and the viable cells number $(\mathrm{CFU} / \mathrm{ml})$ was determined by plating diluted cell suspensions on TY plates. The colonies were counted on agar plates after incubation during $24 \mathrm{~h}$ at $28 \pm 2{ }^{\circ} \mathrm{C}$. All determinations were made by triplicate. Also, appropriate dilutions of free cell cultures were used to determine viable cell number of the controls.

\subsection{Toxicity evaluation of phenol biodegradation products}

The toxicity of phenol solutions after treatment with Acinetobacter sp. RTE1.4 was evaluated using Microtox Acute Toxicity Test $\left(\right.$ Microtox $\left.^{\circledR}\right)$.

Removal reactions were carried out in Erlenmeyers flasks containing MM supplemented with phenol (600 mg/L) and inoculated with Acinetobacter sp. RTE1.4 (10\% V/V, OD $620 \mathrm{~nm} 0.9 \pm 0.1$ equivalent to $\left.2.2 \pm 0.87 \times 10^{11} \mathrm{CFU} / \mathrm{mL}\right)$. They were incubated at $28 \pm 2{ }^{\circ} \mathrm{C}$ in an orbital shaker at $100 \mathrm{rpm}$ until phenol was completely degraded. Then, they were centrifuged during $20 \mathrm{~min}$ at $1,000 \mathrm{rpm}$ and the supernatants were used for toxicity evaluation. These solutions were named as post-removal solutions (PRS). Moreover, the toxicity of MMand MM plus $600 \mathrm{mg} / \mathrm{L}$ phenol were also evaluated as controls.

Microtox $^{\circledR}$ test is based on measuring changes in the light emitted by a nonpathogenic naturally luminescent marine bacterium (Vibrio fischeri) upon exposure to toxic substances. The response to toxicants affecting the bacterial metabolism is observed as a reduction in luminescence, which is a by-product of cellular respiration. This change is measured after $30 \mathrm{~min}$ and can be directly correlated to toxicity. The test was performed following the Standard Protocols and the results were expressed as percentage of effective concentration (EC50\%) [16,17].

2.7 Analytical methods

2.7.1 Determination of phenol metabolism intermediates

HPLC analysis was carried out in a Perking Elmer Clarus 500 chromatographer attached to a PDA UV detector at $280 \mathrm{~nm}$ by injecting $10 \mu \mathrm{L}$ of samples onto a Waters Chrompax C18 analytical column (4.6 mm internal diameter x $150 \mathrm{~mm}$ length). The mobile phase consisted of water with $0.1 \%(\mathrm{v} / \mathrm{v})$ of acetic acid delivered at $1.0 \mathrm{~mL} / \mathrm{min}$. The column was held at a temperature of $30{ }^{\circ} \mathrm{C}$. The total chromatographic run time was $27.0 \mathrm{~min}$. Solvents were of HPLC grade and commercial standards of phenol (Merck), catechol (Fluka AG) and cis,cis-muconic acid (Sigma, Aldrich, Argentina) were used to detect the compound by co-elution.

\subsubsection{Biomass determination}


Samples of bacterial cultures were taken and evaluated for biomass estimations with a Beckman spectrophotometer DU640 by measuring its $\operatorname{OD}_{620 \mathrm{~nm}}[18,19]$. These values were converted to dry weight by a calibration curve, which was obtained by plotting dry weight of biomass vs. OD $_{620 \mathrm{~nm}}$. For determinations of dry weight, culture samples were centrifuged and dried subsequently at $80^{\circ} \mathrm{C}$ until a constant weight was obtained.

\subsubsection{Phenol determination}

Phenol determinations were carried out following the method of Wagner and Nicell [20]. Aliquots of $100 \mu 1$ of each sample were mixed with $100 \mu \mathrm{l}$ of 4-aminoantipyrine $(20.8 \mathrm{mM}), 100 \mu 1$ potassium ferricyanide $(83.4 \mathrm{mM})$ and $700 \mu \mathrm{l}$ of $0.25 \mathrm{M}$ sodium bicarbonate ( $\mathrm{pH}$ 8.4). After five minutes, the absorbance of the coloured compound formed was determined at $510 \mathrm{~nm}$. Phenol concentrations were calculated using a calibration curve, which was performed using known concentrations of pure phenol.

\subsection{Statistical analysis}

Statistical analysis was performed using STATISTICA 7.1 software package. All data were analyzed using ANOVA. In all cases differences between data were considered statistically significant at $p \leq 0.05$. Dunnett test was used to compare several treatment groups with a control.

\section{RESULTS AND DISCUSSION}

\subsection{Identification of the strain at the species-level}

In the present work we show complementary new results to improve the identification of Acinetobacter sp. RTE1.4 strain at species level, because the 16S rRNA gene is not sufficiently polymorphic to clearly distinguish all closely related genomic species of Acinetobacter [12 and references there in]. Thus, we analyzed the sequence of the housekeeping gene recA, which seems to be one of the most useful tools for the identification and taxonomic classification of yarious bacterial species, including Acinetobacter spp [21,8]. The recA gene was amplified and sequenced using the pair of primers rA1 and rA2. A fragment of $356 \mathrm{bp}$ (Fig. 1) was obtained, sequenced and subsequently aligned using online BLAST tool. It had a $99 \%$ sequence similarity with different strains of the tandoii species. The gene sequence was deposited in GeneBank (accession number JX258136).

A phylogenetic tree was constructed based on sequences of this gene. Fig. 2 shows the phylogenetic relationship of Acinetobacter sp. RTE1.4 with other species of Acinetobacter genus. As it can be seen in the figure, the recA gene sequence of Acinetobacter sp. RTE1.4 showed closest relation with two strains of $A$. tandoii, CT33 and CCUG 56317 , forming a cluster in which the homology between them was high (99\%).

In addition, a rapid, high-throughput identification method, mass spectrometry (MALDI-TOF- MS) was use to confirm this results because it has been demonstrated to be effective for the identification of several microorganisms. The main advantages of MALDI-TOF MS are that species can be routinely identified quicker than with DNA sequence analysis, costs are not extremely high and no external conditions such as culture medium or conditions can affect the 
result. As was pointed out earlier score values $\geq 2.0$ were considered appropriate for identification at species level. Thus, the obtained score $(>2.05)$ yielded high-confidence identification at the species level for the studied strain with $100 \%$ concordance with the molecular method. Therefore, the studied strain displayed identical identification at genus and species level using a combination of genetic and spectrometric analysis, resulting in a correct identification of the strain, as $A$. tandoii.

Thus, the results presented in this work, along with those of the 16S rDNA gene sequencing and biochemical tests previously performed [7], confirmed that the studied strain belongs to Acinetobacter genus and, particularly, corresponds to tandoii species. Because of this, it was named as Acinetobacter tandoii RTE1.4.

\subsection{Evaluation of reaction intermediates of phenol metabolism}

Previously, we proposed that Acinetobacter sp. RTE1.4 degrade phenol by the ortho-pathway [7]. In the present work we try to find out the presence of specific metabolites of this path by HPLC analysis of the supernatants of samples, in which phenol was almost degraded.

A single chromatographic condition, showing high signal-to-noise ratio, was optimized in order to detect the presence of catechol (tR $10.76 \mathrm{~min}$ ), cis,cis-muconic acid (tR $15.51 \mathrm{~min}$ ) and phenol (tR $22.78 \mathrm{~min}$ ) in the above mentioned matrix. An example chromatogram is shown in Fig. 3 were peaks 1, 3 and 5 correspond to catechol, muconic acid and phenol, respectively, while peaks 2 and 4 are unidentified products, assumed to be other intermediate compounds produced during phenol cleavage.

In our previous studies, we detected only catechol 1,2-dioxigenase activity in A.tandoii RTE1.4, suggesting that this strain would metabolize phenol by the ortho-pathway [7]. In the present work, the presence of cis,cis-muconic acid and catechol in the metabolized media confirmed this hypothesis.

This result is in agreement with those described by Saxena et al. [21], which showed the presence of catechol as a phenol degradation product in culture medium of Acinetobacter strains. However, these authors could not demonstrate the presence of $c i s, c i s$-muconic acid, as it was observed in the present work. In this sense, the cis,cis-muconic acid production has been reported for different microbial strains that degrade phenol by ortho-pathway [22, 23,24] but, to our knowledge, the finding of this specific intermediate as result of phenol degradation by Acinetobacter strains was not reported so far.

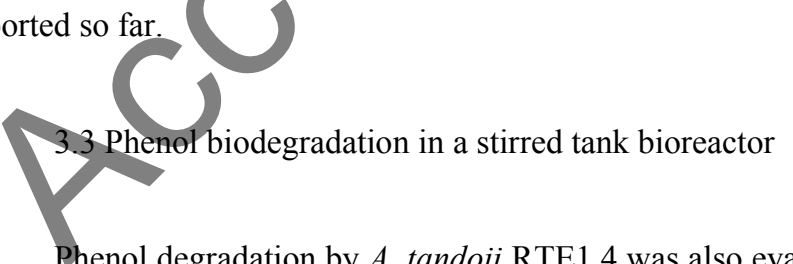

system. In these experiments, different aeration and agitation conditions were assayed in order to improve removal efficiencies of higher volumes (2 L) of solutions containing phenol compared with those obtained in Erlenmeyers flasks [8].

When aeration of $1 \mathrm{vvm}$ was used (Fig. 4a), no difference was observed in the removal efficiency between the three agitation rates used $(200,400$, and $600 \mathrm{rpm})$ until $4 \mathrm{~h}$ of cultivation. However, after 6 to $8 \mathrm{~h}$, different phenol removal efficiencies $(p \leq 0.05)$ were found and complete phenol degradation was attained after $7 \mathrm{~h}$ of treatment at 600 
rpm whereas at 200 and $400 \mathrm{rpm}$ the remaining phenol was completely removed after $8 \mathrm{~h}$. The growth of the microorganism increased as phenol biodegradation occurred, reaching similar dry weight values for the three assayed agitation rates at the end of these assays ( $p>0.05)$ (Fig. $4 b)$.

When aeration was increased to 3 vvm (Fig. 4c), 93.5\% of degradation was observed after only 6 h under 600 rpm, reaching complete phenol biodegradation after $7 \mathrm{~h}$ under this condition. When agitation rate was decreased (200 and $400 \mathrm{rpm})$, complete removal of the contaminant was achieved $(8 \mathrm{~h})$. DW was similar at end of the assay $(0.2 \mathrm{~g} / \mathrm{L})$ for 200 and $400 \mathrm{rpm}$ and was highlight higher when $600 \mathrm{rpm}$ of agitation were used, although this difference was not statistically significant $(p>0.05)$.

Phenol removal was also evaluated in a bioreactor operating without bacterial inoculation under all agitation and aeration conditions used. Only an insignificantly loss of the contaminant (means of $8 \%$ ) was observed as a result of evaporation $(p>0.05)$.

These assays demonstrated the possibility of process scale, allowing the efficient removal of 2 L of phenol contaminated solution. As it was shown, complete phenol $(200 \mathrm{mg} / \mathrm{L})$ degradation by A. tandoii RTE1.4 was detected in short periods of time under the assayed experimental conditions, however the prøcess was faster (in only $6 \mathrm{~h}$ ) at high agitation rates $(600 \mathrm{rpm})$ and air flows $(3 \mathrm{vvm})$. Similar results were found by Agarry et al. [25], since the optimum process conditions for maximizing phenol $(100 \mathrm{mg} / \mathrm{L})$ removal by a Pseudomonas fluorescens strain were: aeration 3.0 vvm and agitation $300 \mathrm{rpm}$. However, this bacterium was able to reach lower percentage of phenol degradation (60.7\%) compared with that reached with $A$. tandoii RTE1.4 for $200 \mathrm{mg} / \mathrm{L}$ of phenol. Using other kind of bioreactor such as batch jet loop bioreactor (JLB) with activated sludge and mixed culture, a complete degradation of phenol up to the initial concentration of $500 \mathrm{mg} / \mathrm{l}$ occurred in less than $5 \mathrm{~h} \mathrm{[26].}$

The higher removal at high agitation yalues and air flows found for A. tandoii RTE1.4 could be attributed to the high requirements of forceful agitation and oxygenation of the strain for an efficient performance of the biochemical process. In this sense, Hoq et al. [27] indicated that an increase in agitation rates and air flows may lead to a high biodegradation rate due to a better mass transfer, allowing more dissolved oxygen available for microorganism metabolism. Furthermore, it has been described that a low agitation may result in the formation of regions of poor nutrient content or inadequate temperature or $\mathrm{pH}$. Therefore, as a general result, the productivity of the process declines [28]. It is noteworthy that biomass resisted the hydrodynamic stress produced by high turbulence of the media, which is relevant because it has been described that several strains are affected by this conditions and die during the process $[25,29,30]$. However, it is important to remark than the difference in the required time for a complete phenol removal comparing all the conditions (different rpm and vvm) was 1 to 2 hours between the more and less favorable condition, thus this gain in time would be less important considering the high energy consumption. The energy consumption of a bioreactor system should be minimized to enable a sustainable operation, thus $1 \mathrm{vvm}$ and $200 \mathrm{rpm}$ could be selected to reach a complete phenol removal of $2 \mathrm{~L}$ contaminated solution in only $7 \mathrm{~h}$ using $A$. tandoii RTE1.4 with lower energy cost compared with the other probed conditions.

The behavior of $A$. tandoii RTE1.4 in the bioreactor differed from those previously obtained in Erlenmeyer flasks [7] since the degradation of $200 \mathrm{mg} / \mathrm{L}$ of phenol was faster in bioreactor, allowing a reduction of $85 \%$ in the time required for complete degradation comparing with Erlenmeyers. This result clearly shows the importance of a proper selection of agitation and aeration conditions, as was previously demonstrated for other bacterial strains $[31,32]$. 
Therefore, the results obtained in the bioreactor allowed us to know the conditions of agitation and aeration to maximize growth and degradation metabolism. These findings are relevant taking into account that this bacterium was also able to remediate different industrial effluents [33], which are frequently treated using bioreactors. However, other more easily scalable alternative and of practical use can be packed bed reactor using bacterial associated in biofilm or immobilized in different matrix to reach high contaminant removal from wastewater [34]. In this sense, operation variables of a batch reactor such as impeller speed and aeration rate, that can make it difficult to scale the process and limit its use should not be a problem.

\subsection{Phenol biodegradation using alginate immobilized cells}

\subsubsection{Phenol removal evaluation}

Phenol biodegradation by immobilized bacteria was studied and compared with the catalytic efficiency of free cell cultures (Fig. 5).

Immobilized cells completely degraded 200, 600 and 1,000 mg/L of phenol in $3 \mathrm{~d}$ while free cells removed only 83,70 and $45 \%$ of initial phenol respectively, even after $6 \mathrm{~d}$ of incubation $(p \leq 0.05$ ) (Fig $5 \mathrm{a})$. Due to these results, it was decided to increase the concentration of the contaminant to 2,000 and 2,500 $\mathrm{mg} / \mathrm{L}$ where immobilized cells removed 64 and $22.6 \%$ of phenol, respectively, after $20 \mathrm{~d}$ of treatment $(p \leq 0.05)$ whereas free cells were unable to degrade significant amount of the contaminant (Fig 5b).

Protein content was also evaluated at the beginning and at the end of each assay (Table 1). The protein concentration of the beads containing A. tandoii RTE1.4 cells as well as of the reaction medium did not show significant changes $(p>0.05)$ at the end of the experiment for all the evaluated concentrations. Contrarily, in free cell cultures a significant increase $(p \leq 0.05)$ in protein content was detected for all studied phenol concentrations.

Viable cell number was also determined in alginate beads and free cell cultures. Inoculated beads contained $2 \times 10^{12} \mathrm{CFU} / \mathrm{mL}$ while the free cell inocula contained $2.2 \times 10^{11} \mathrm{CFU} / \mathrm{mL}$. These results correlate with protein content previously determined, because biomass was higher in beds than in free cells extracts. Protein content and viable cell number were not detected in the reaction media of the beads indicating that there was not cell leakage from them.

No significant phenol loss $(p>0.05)$ by calcium alginate adsorption or by evaporation was detected in abiotic controls.

The results obtained using immobilized $A$. tandoii RTE1.4 were consistent with previous reports which indicate that bacterial cells immobilized in different matrices have advantages compared with free cell cultures such as higher tolerance and removal efficiencies to different contaminants [35,36,37]. Besides, alginate has been described as an appropriate matrix for bacterial cells immobilization [13,38,39], as it was also observed in this work. Immobilized $A$. tandoii RTE1.4 was able to degrade phenol even at high concentrations as 2,000 $\mathrm{mg} / \mathrm{L}$, concentration at which free cells were unable to significantly degrade phenol. Similarly, Pishgar et al. [40] found that removal efficiency of phenol at $1000 \mathrm{mg} / \mathrm{L}$ was enhanced from 10 to about $40 \%$ in the presence of immobilized cells compared with free cells, although the percentage of removal was lower compared with immobilized A. tandoii RTE1.4 cells.

In this sense, different authors have demonstrated the reduction in phenol degradation due to its toxic effects at high concentrations when free cells are used, which can be reduced when bacteria are immobilized. Probably, it can be 
attributed to the high cell density contained in beads as well as to the protection given by the polymeric matrix [41]. In the present work, a higher cellular density was detected in alginate beads compared to free cell cultures, which could explain the high phenol degradation observed. Moreover, protein content in beads and in reaction medium remained constant, suggesting that the beads maintain their integrity during the biodegradation process, without release of cells to the reaction medium. Thus, immobilization represents an advantage for bioremediation processes because cells remain entrapped in the polymeric matrix that provides protection to the microorganisms, ensures their prolonged viability and allows the repeated use of their catalytic activity.

In addition, immobilization can also be considered for the scale up of the process in a bioreactor. Gonzalez et al. [42] applied calcium-alginate gel beads of pure strain of Pseudomonas putida for degrading phenol in a fluidized bed reactor. Over $98 \%$ of phenol with concentration of $250-2000 \mathrm{mg} / 1$ was removed by immobilized bacteria. Among the immobilized cell bioreactors, no doubt the fluidized or semi-fluidized bed bioreactor is a novel and efficient one, which can be adopted for the treatment of industrial wastewater containing phenolic compounds and other pollutants even at lower concentration. However, a proper choice of immobilized culture and careful consideration of various design parameters should be considered in order to make the remediation process cost effective in the long run [43].

3.4.2 Reusability and stability during storage of immobilized cells

Taking into account that one of the advantages of immobilized cells is their reusability, immobilized $A$. tandoii RTE1.4 cells were used for repeated cycles of phenol biodegradation. The beads were used for 4 consecutive cycles, in which the rate of the process was significantly reduced $(p \leq 0.05)$ over time from $15.4 \pm 1.6$ to $12.4 \pm 4.7 \mathrm{mg} / \mathrm{L} \mathrm{h}$.

On the other hand, phenol biodegradation capability of $A$. tandoii RTE1.4 immobilized cells was evaluated after different storage times at $4{ }^{\circ} \mathrm{C}$. It was observed that immobilized bacteria retain their catalytic activity for 9 months, in which the maximum degradation efficiency was kept (100\%). This high stability during storage at $4{ }^{\circ} \mathrm{C}$ indicates that the enzymatic activity was maintained for many months.

The reusability and stability of immobilized cells during storage are essential factors for their applicability in a bioremediation system. It is important to note that the removal rate of the contaminant by A. tandoii RTE1.4 immobilized cells was progressively reduced during the experiment, indicating a decrease of the enzymatic activity and, possibly, of the cellular viability. These results can be probably attributed to the interference of some reaction products adsorbed to the matrix, which modify its mechanic stability, altering the diffusion of the contaminant or reducing the catalytic activity of the involved enzymes as was also described for other immobilized bacteria [41]. Thus, it would be the reason for the reduction in the process rate. However, it is noteworthy that, after four cycles, all phenol was completely degraded even at low rate.

Thus, immobilized cells of A. tandoii RTE1.4 could be applied for efficient remediation of high phenol concentrations that free cells could not remove. They could also be reused by four consecutive cycles and be stored at 4 ${ }^{\circ} \mathrm{C}$ by 9 months, which emphasizes the advantage of bacterium immobilization in calcium alginate for phenol removal.

3.5 Toxicity evaluation of phenol biodegradation products 
Following the phenol biodegradation process, it is interesting to evaluate the toxicity of the PRS in order to establish if they are safe and can be released into the environment. These studies were carried out through the Microtox test which is a standard method for determining the toxicity of aqueous wastes before and after biological treatments. The obtained results are shown in Table 2.

Culture media showed an $\mathrm{EC}_{50}$ higher than 90\%, which indicates a low reduction of the lumminiscense of $V$. fischeri and, consequently, a low toxicity. When these media were supplemented with $600 \mathrm{mg} / \mathrm{L}$ of phenol, a high reduction of the lumminiscense was observed reaching values of $\mathrm{EC}_{50}$ of only $3.1 \%$. However, when these solutions were treated with A. tandoii RTE1.4, a significant increase in the EC50 was achieved, reaching similar values than the culture medium without the contaminant.

These results clearly indicated that PRS did not produce toxic effects on the exposed organism, which highlight the detoxificant effect of $A$. tandoii RTE1.4 treatment. In addition, it was possible to suggest that during degradation reactions, toxic intermediates would not be produced, at least for $V$. fischeri. The toxicity of remaining solutions, after a bioremediation processes, may differ depending on the studied organism. Hence, a set of toxicity assays including different organisms could be used for the evaluation of the toxic impacts of PRS derived from A. tandoii RTE1.4 treatment. These studies are now being carried out in our laboratory to confirm if this treatment could be applied, without negative impacts on the environment.

Clearly, the integration of chemical analysis, ecotoxicity, and remediation potential data is required to properly assess ecological risk in the management and treatment of contaminants. Despite this, the results obtained in the present work until now could be considered sure since Microtox ${ }^{\mathbb{R}}$ is a validated technique for bioremediation studies and it is currently recommended by the US EPA $[44,45,46]$.

\section{CONCLUSION}

In this work, a combined approach of molecular tools and MALDI-TOF MS strategy was used to accurately identify the studied strain at species level as Acinetobacter tandoii RTE1.4. This identification was achieved through the analysis of the housekeeping gene $r e c \mathrm{~A}$, one of the most useful tools for the identification and taxonomic classification of various bacterial species, including Acinetobacter sp and, also, by MALDI-TOF MS, which is increasingly used in the field of bacterial taxonomy.

This strain was capable to efficiently degrade phenol by ortho fission of the aromatic ring, producing intermediates sueh as catechol and cis,cis-muconic acid. The results showed that bioremediation process could be scaled up in a 5-L bioreactor reaching complete phenol removal of 2-L contaminated solution (phenol $100 \mathrm{mg} / \mathrm{L}$ ) in short time. However, the air flow and agitation speed conditions determined as optimal for an efficient phenol removal in the batch reactor should be selected considering a lower energy cost.

Immobilization of $A$. tandoii RTE1.4 was shown as a possible strategy to reach efficient remediation of high phenol concentrations, even with the advantage that beads of calcium alginate containing the bacterium could be reused by four consecutive cycles and stored at $4{ }^{\circ} \mathrm{C}$ by a long period ( 9 months) without losing activity. 
Considering that toxicity testing should be an integral part of a bioremediation process we evaluate the presence of toxic intermediates after phenol removal. The toxicity test (Microtox ${ }^{\circledR}$ ) revealed that phenol treated solutions with $A$. tandoii RTE1.4 were not toxic, ensuring the safety of the treated solutions.

The performance shown by $A$. tandoii RTE1.4 makes this strain a good candidate to efficiently remove great volumes of phenol in bioreactors and highly concentrated solutions, even at those concentrations than free cells were not able to remove, with immobilized cells. The good reusability and long life of immobilized cells represent an interesting advantage for the possible application to real contaminated samples remediation, as wastewater, and to be considered for bioreactor design in order to develop a sustainable biotechnology process.

References

[1] Iurascu B, Siminiceanu I, Vione D, Vicente MA, Gil A. Phenol degradation in water through a heterogeneous photo-fenton process catalyzed by Fe- treated laponite. Water Res. 2009:43:1313-1322.

[2] U.S. Environmental Protection Agency (USEPA), Generalized methodology for Conducting Industrial reduction evaluations TREs, EPA 600/2-88/070, 1989

[3] Ley Nacional Argentina No 24.051 Decreto 831/93. Reglamentación de Residuos Peligrosos, http://www.cecopal.org/dereccho/DNacional/DN-831-93.htm.

[4] Busca G, Berardinelli S, Resini C, Arrighi L. Technologies for the removal of phenol from fluid streams: Ashort review of recent developments. J Hazard Mat. 2008; 160:265-288.

[5] Tuah PBM. The performance of phenol biodegradation by Candida tropicalis retl-cr1 using batch and fedbatch fermentation techniques. Tesis para acceder al grado de doctor en filosofía. Faculty of Science, Universiti Teknologi Malaysia. 2006.

[6] Pandey B, Fulekar MH. Bioremediation technology: A new horizon for environmental clean-up. Biol. Medicine. 2012;4(1):51-59,

[7] Paisio CE, Talano MA, González PS, Pajuelo-Domínguez E, Agostini E. Characterization of a phenoldegrading bacterium isolated from an industrial effluent and its potential application for bioremediation. Environ Tech. 2013;34(4):485-493.

[8] Nowak A, Kur J. Genomic species typing of Acinetobacters by polymerase chain reaction amplification of the recA gene. FEMS Microbiol Lett. 1995;130(2-3):327-332.

[9] Altschul SF, Madden TL, Schäffer AA, Zhang J, Zhang Z, Miller W, Lipman DJ. Gapped BLAST and PSIBLAST: a new generation of protein database search programs. Nucleic Acids Res. 1997;25:3389-3402. http://www.ncbi.nlm.nih.gov/sutils/genom_table.cgi.

[10] Tamura K, Dudley J, Nei M, Kumar S. MEGA4: Molecular evolutionary genetics analysis (MEGA) software version 4.0. Mol Biol Evol. 2007;24:1596-1599.

[11] Cattani ME, Posse T, Hermes RL, Kaufman SC. Rapid identification of microorganisms by mass spectrometry in a blood culture system. Comparison of two procedures. Rev Argent Microbiol. 2015;47(3):190-195. 
[12] Álvarez-Buylla A, Culebras E, Picazo JJ. Identification of Acinetobacter species: Is Bruker biotyper MALDI-TOF mass spectrometry a good alternative to molecular techniques? Infec., Gen. and Evol. 2012;12: 345-349.

[13] Mollaei M, Abdollahpour S, Atashgahi S, Abbasi H, Masoomi F, Rad I, Lotfi AS, Zahiri HS, Vali H, Noghabi KA. Enhanced phenol degradation by Pseudomonas sp. SA01: gaining insight into the novel single and hybrid immobilizations. J Hazard Mater. 2010;175(1-3):284-292.

[14] Bradford MM. A rapid and sensitive method for quantitation of microgram quantities of protein utilizing the principle of protein-dye-binding. Anal Biochem. 1976;72:248-254.

[15] Sossa Urrego D, Navarro Acevedo MA, Matiz Villamil A, Mercado Reyes M, Quevedo Hidalgo B, Pedroza Rodríguez A. Immobilization of Bacillus licheniformis and Saccharomyces cerevisiae for ethanol production from potato starch. Universitas Scientiarum. 2008;13:149-161

[16] Van der Grinten E, Pikkemaat MG, Van den Brandhof EJ, Stroomberg GJ, Kraak MHS. Comparing the sensitivity of algal, cyanobacterial and bacterial bioassays to different groups of antibiotics. Chemosphere 2010; 80: 16.

[17] Mansour SA, Abdel-Hamid AA, Ibrahim AW, Mahmoud NH, Moselhy WA. Toxicity of some pesticides, heavy metals and their mixtures to Vibrio fischeri bacteria and Daphnia magna: comparative study. J. of Biology and Life Sci. 2015;6 (2): 221-240.

[18] Courties A, Riedel T, Rapaport A, Lebaron P, SusuKy MT. Light-driven increase in carbon yield is linked to maintenance in the proteorhodops in-containing Photobacterium angustum S14. Front Microbiol. 2015;6: 688. doi: 10.3389/fmicb.2015.00688

[19] Alibayov B , Karamonova L, Hollerova R, Zdenkova K, Demnerova K. Differences in transcription and expression of staphylococcal enterotoxin C in processed meat products. LWT - Food Sci. and Technol. 2015;64 (2): 578-585.

[20] Wagner M, Nicell JA. Detoxification of phenolic solutions with horseradish peroxidase and hydrogen peroxide. Water Res. 2002;36:4041-4052.

[21] Saxena M, Gupta S, Rita Kumar M, Kumar A. Identification and genetic characterization of phenol degrading bacterium isolated from oil contaminated soil. African J Biotechnol. 2013;12(8):791-797.

[22] Wurster M, Mundt S, Hammer E, Schauer F, Lindequist U. Extracellular degradation of phenol by the cyanobacterium Synechococcus PCC 7002. J Applied Phycol. 2003;15(2):171-176.

[23] Mohd. Tuah P, Rashid NAA, Salleh M. Degradation pathway of phenol through -cleavage by Candida tropicalis RETL-Cr1. Borneo Sci. 2009;24:1-8.

[24] Veenagayathri K, Vasudevan N. Ortho and meta cleavage dioxygenases detected during the degradation of phenolic compounds by a moderately halophilic bacterial consortium. Int Res J Microbiol. 2011;2(10): 406-414.

[25] Agarry SE, Solomon BO, Audu TOK. Optimization of process variables for the batch degradation of phenol by Pseudomonas fluorescence using response surface methodology. Int J Chem Technol. 2010;2:33-45.

[26] Ucun H, Yildiz E, Nuhoglu A. Phenol biodegradation in a batch jet loop bioreactor (JLB): Kinetics study and $\mathrm{pH}$ variation. Biores Technol 2010;101:2965-2971.

[27] Hoq MM, Solomon BO, Hempel C, Rinas U, Deckwer WD. The kinetics of cellulase-free xylanase excretion by Thermomyces lanugiosus RT 9. J Chem Technol Biotechnol. 1995;63:229-236. 
[28] Namved PK, Dunlop EH, Wenger K, Villeneuve P. Role of turbulence in fermentations. En: Advances in bioprocesses engineering. Galindo E., Ramírez O.T. Eds. Kluwer Academic Publishers, Dordrecht, Países Bajos. pp. 149-156. 1994.

[29] Hodaifa G, Martínez ME, Órpez R, Sánchez S. Influence of hydrodynamic stress in the growth of Scenedesmus obliquus using a culture medium based on olive-mill wastewater. Chem Eng Processing. 2010;49:11611168.

[30] Paisio CE, Talano MA, González PS, Busto VD, Rodríguez Talou J, Agostini E. Isolation and characterization of a Rhodococcus strain with phenol degrading ability and its potential use for tannery effluent biotreatment. Environ Sci Pollut Res. 2012;19(8):3430-3439.

[31] Alam MNHZ, Razali F. Scale-up of stirred and aerated bioengineering ${ }^{\text {TM }}$ bioreactor based on constant mass transfer coefficient. J Technol. 2005;43:95-110.

[32] Khleifat KM. Biodegradation of phenol by Ewingella americana: Effect of carbon starvation and some growth conditions. Process Biochem. 2006;41:2010-2016.

[33] Paisio CE, Quevedo MR, Talano MA, González PS, Agostini E. Application of two bacterial strains for wastewater bioremediation and assessment of phenolics biodegradation. Environ Technol. 2014;35(14):1802-1810.

[34] Dey S, Mukherjee S. Kinetic Studies for an Aerobic Packed Bed Biofilm Reactor for Treatment of Organic Wastewater with and without Phenol J. Water Res Protect 2010;2:731-738.

[35] Quek E, Ting YP, Tan HM. Rhodococcus sp. F92 immobilized on polyurethane foam shows ability to degrade various petroleum products. Biores Technol. 2006;97:32-38.

[36] Ahamad A, Kunhi M. Enhanced degradation of phenol by Pseudomonas sp. CP4 entrapped in agar and calcium alginate beads in batch and continuous processes. Biodegradation. 2011;22(2):253-265.

[37] Robatjazi SM, Shojaosadati SA, Khalilzadeh R, Farahani EV, Zeinoddini M. Continuous biodegradation of parathion by immobilized Sphingomonas sp. in magnetically fixed-bed bioreactors and evaluation of the enzyme stability of immobilized bacteria. Biotechnol Lett. 2013;35(1):67-73.

[38] Karigar C, Mahesh A, Nagenahalli M, Yun DJ. Phenol degradation by immobilized cells of Arthrobacter citreus. Biodegradation, 2006;17(1):47-55.

[39] Wang Z, Xu Y, Wang H, Zhao J, Gao D, Li F, Xing B. Biodegradation of crude oil in contaminated soils by free and immobilized microorganisms. Pedosphere. 2012;22(5):717-725.

[40] Pishgar R, Najafpour G, Navayi Neya B, Mousavi N, Bakhshi Z. Anaerobic Biodegradation of Phenol: Comparative Study of Free and Immobilized Growth. Iranica J Energy Environ. 2011; 2(4):348-355.

[41] Tallur N, Megadi VB, Ninnekar HZ. Biodegradation of $p$-cresol by immobilized cells of Bacillus sp. strain PHN 1.Biodegradation. 2009;20(1):79-83.

[42] Gonzalez G, Herrera M, García M, Pena M. Biodegradation of phenol in a continuous process: comparative study of stirred tank and fluidized-bed bioreactors. Biores technol. 2001;76(3):245-251.

[43] Nemati M, Webb C, In: Comprehensive Biotechnology (Second Edition): Volume 2: Engineering Fundamentals of Biotechnology. Second Edition ed. Burlington: Academic Press; 2011. p. 331-346. 
[44] Cotou E, Gremare A, Charles F, Hatzianestis I, Sklivagou E. Potential toxicity of resuspended particulate matter and sediments: Environmental samples from the Bay of Banyuls-sur-Mer and Thermaikos Gulf. Continental Shelf Res. 2005;25(19-20):2521-2532.

[45] Leitão AL, Duarte MP, Santos Oliveira J. Degradation of phenol by a halotolerant strain of Penicillium chrysogenum. Int Biodet Biodeg. 2007;59:220-225.

[46] Mamindy-Pajany Y, Geret F, Roméo M, Hurel C, Marmier N. Ex situ remediation of contaminated sediments using mineral additives: Assessment of pollutant bioavailability with the Microtox solid phase test. Chemosphere. 2012;86(11):1112-1116.

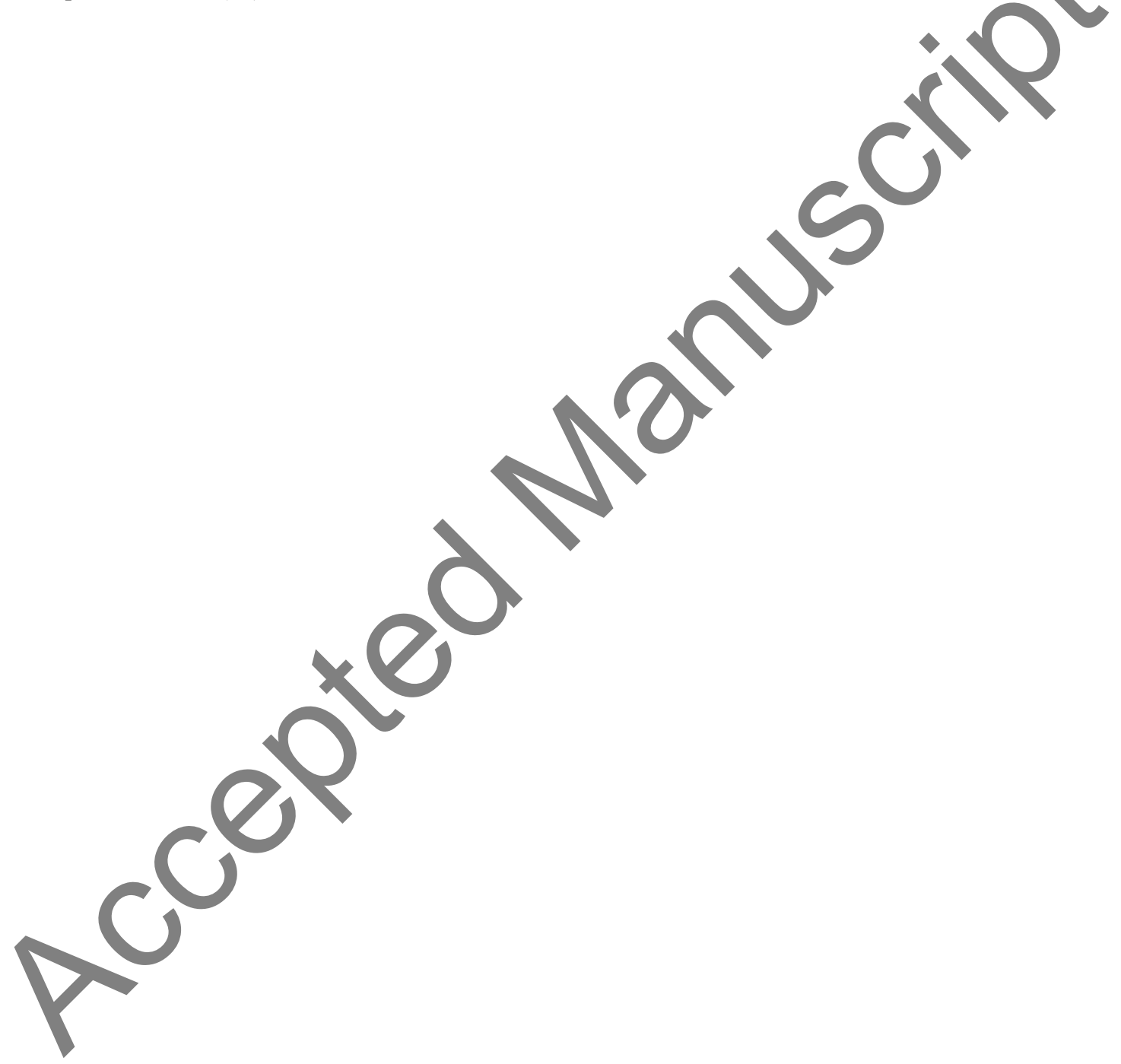


Figure legends

Fig 1. Electrophoretic analysis of amplified product of recA gene by PCR. Lane 1, Acinetobacter sp. RTE1.4 genomic DNA; lane 2, molecular weight marker

Fig. 2. Phylogenetic tree based on recA gene sequence analysis (1000 bootstrap for the confidence level) showing the relationship between Acinetobacter sp. RTE1.4 strain and representative species of Acinetobacter genus. The bacterial species are indicated in the figure by their accession number between parentheses followed by the taxonomical identification. The scale bars represents 5 substitutions per 100 nucleotides.

Fig. 3. Chromatographic profile of supernatants of phenol spiked solutions after treatment by $A$. tandoii RTE1.4 culture. Conditions: $\mathrm{C} 18$ column; water with $0.1 \%(\mathrm{v} / \mathrm{v})$ of acetic acid, flow rate: $1.0 \mathrm{~mL} / \mathrm{min}$; temperature: $25^{\circ} \mathrm{C}$; injection volume $10 \mu \mathrm{L}$.

Fig. 4. Degradation of $200 \mathrm{mg} / \mathrm{L}$ of phenol (a and c) by A. tandoii RTE1.4 and its growth curves (b and d) in a stirred tank bioreactor under different agitation (200-600 rpm) and aeration: $1 \mathrm{vvm}(\mathrm{a}$ and b) and $3 \mathrm{vvm}(\mathrm{c}$ and d).

Ref.: (a) indicates significant differences $(p \leq 0.05)$ of the indicated treatment respect to $400 \mathrm{rpm}$

(b) and (c) indicate significant differences $(p \leq 0.05)$ of the indicated treatments respect to 200 and $400 \mathrm{rpm}$

Fig. 5. Phenol degradation by free and immobilized cells of $A$. tandoii RTE1.4. a) Phenol 200 to 1,000 mg/L; b) Phenol 2,000 and 2,500 $\mathrm{mg} / \mathrm{L}$

Ref.: (*) indicates significant differences $(p \leq 0.05)$ between free and immobilized cells for each phenol concentration

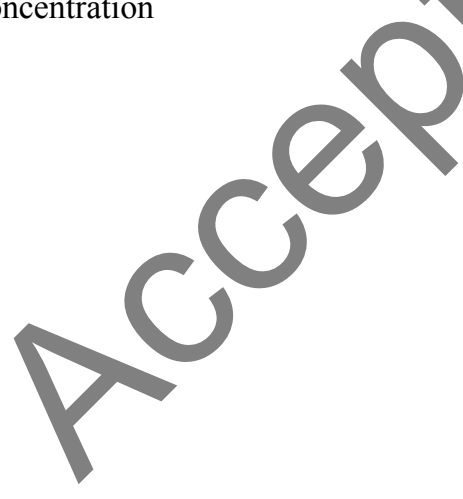




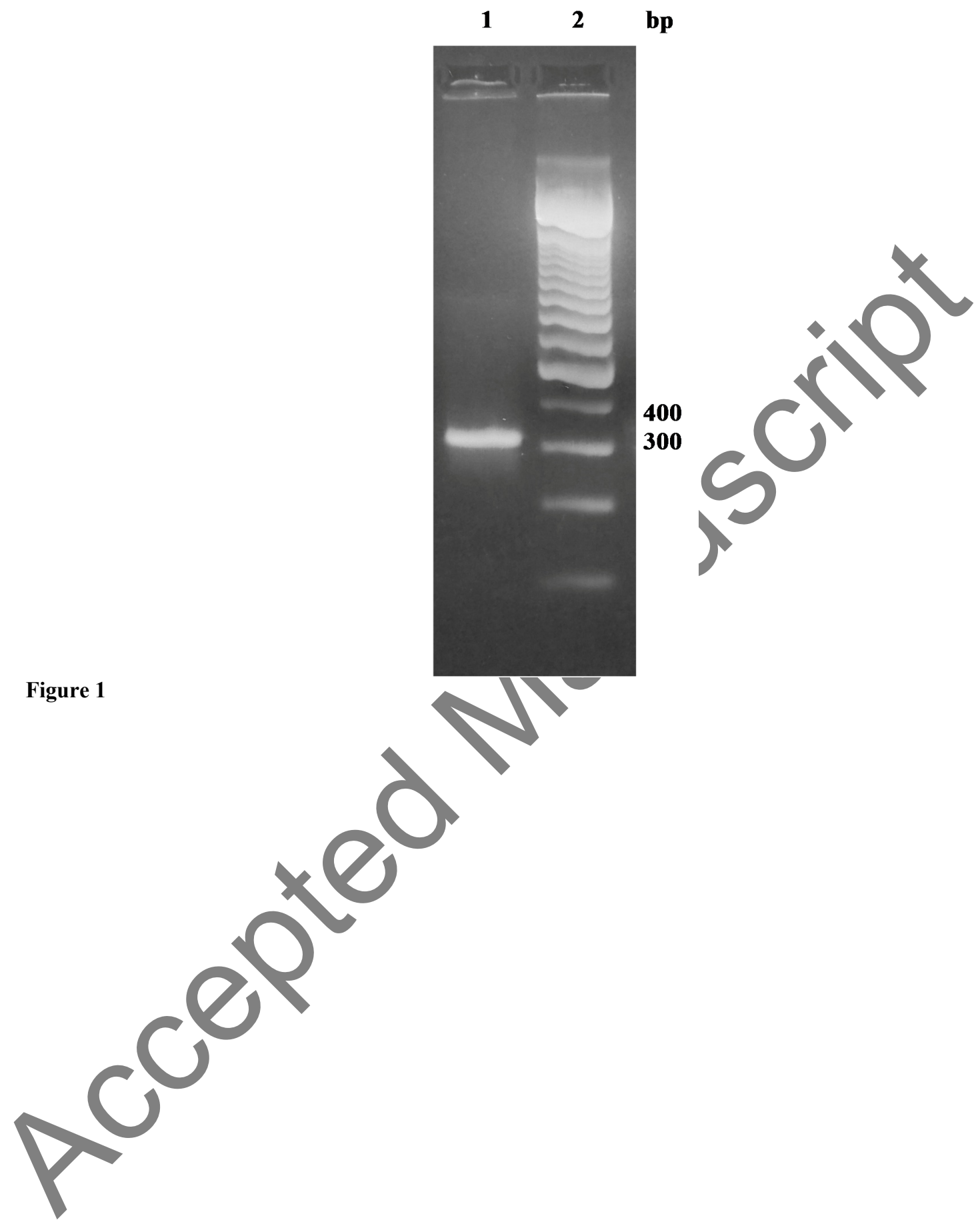




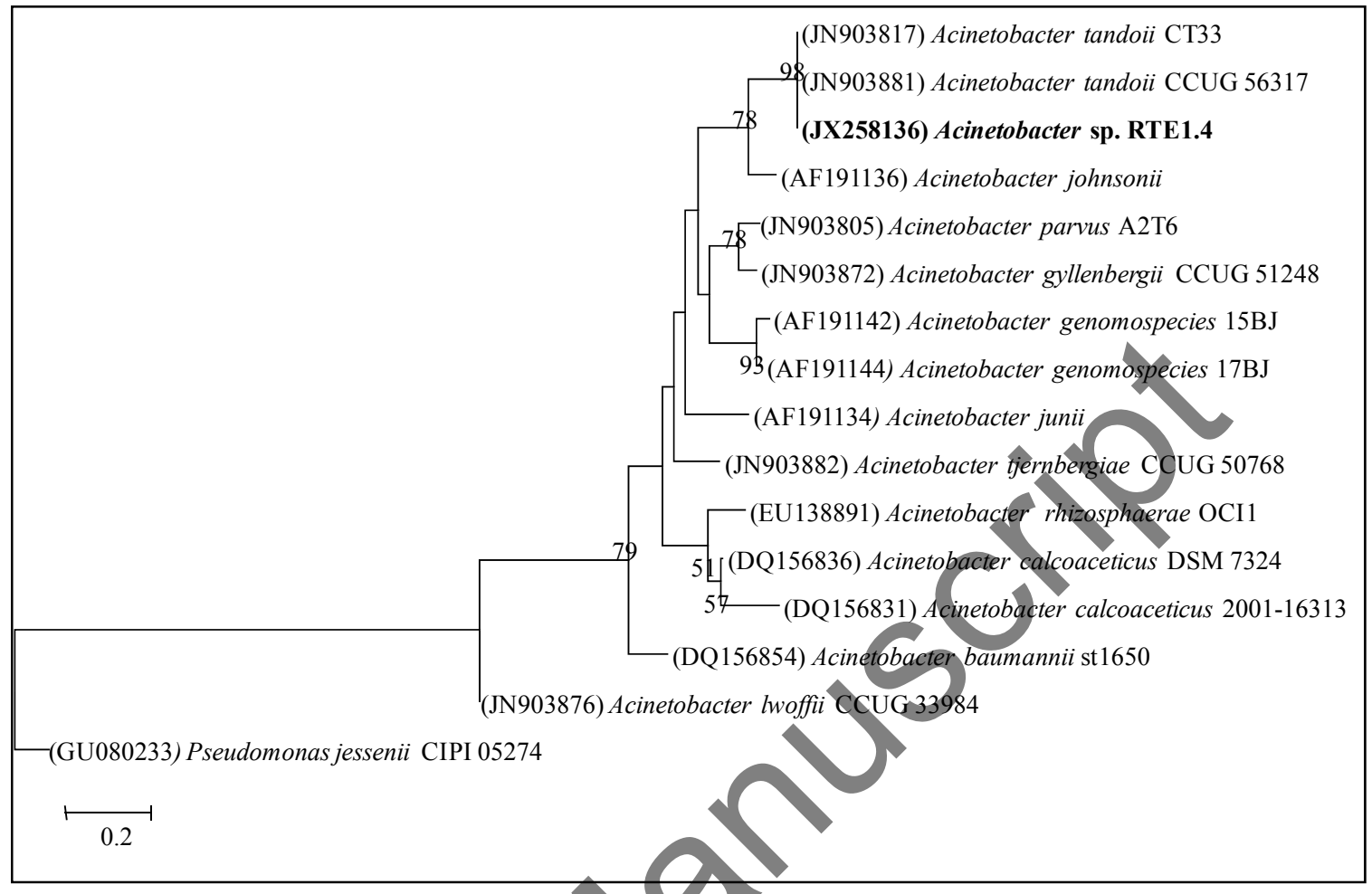

Figure 2 


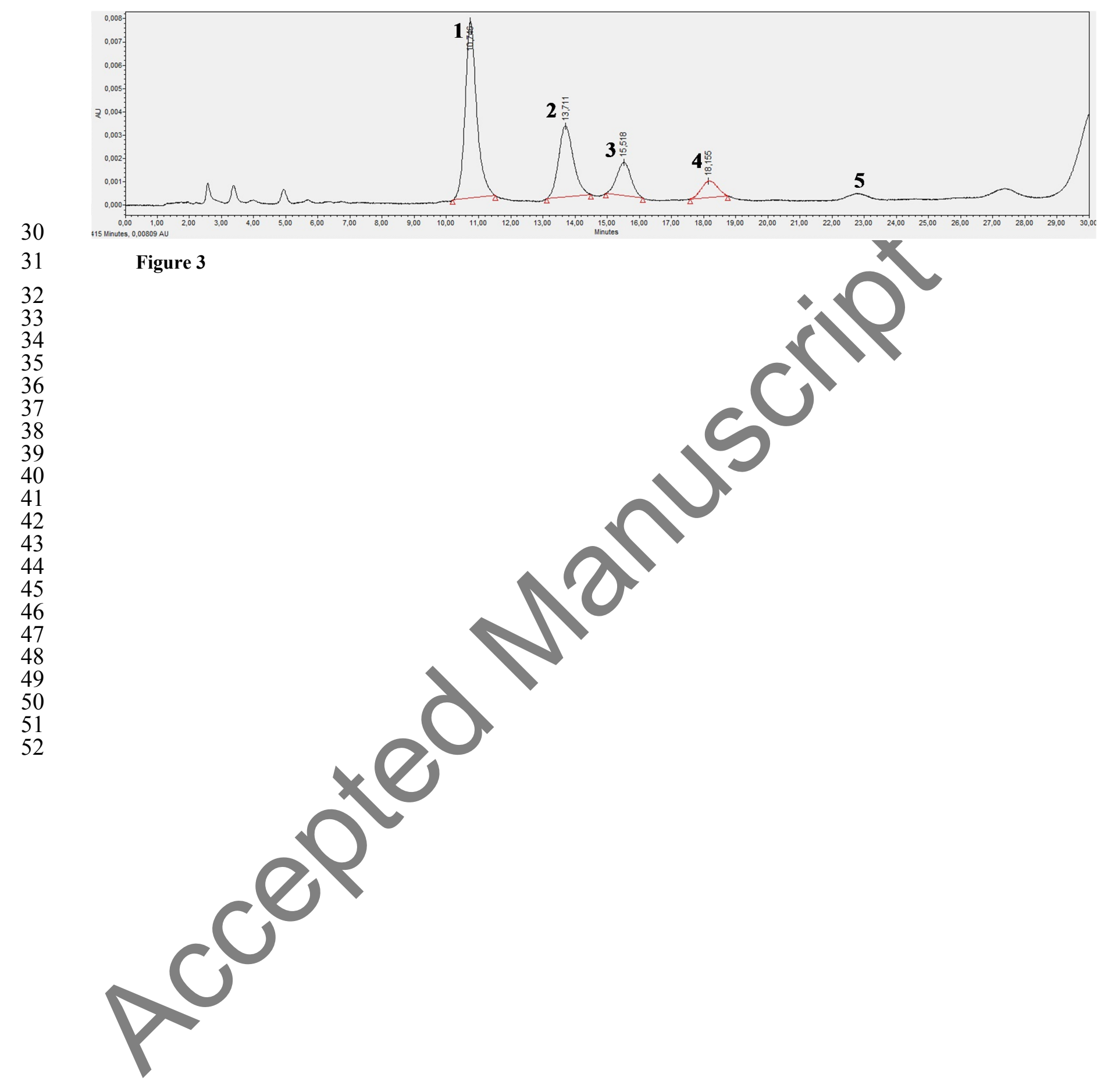




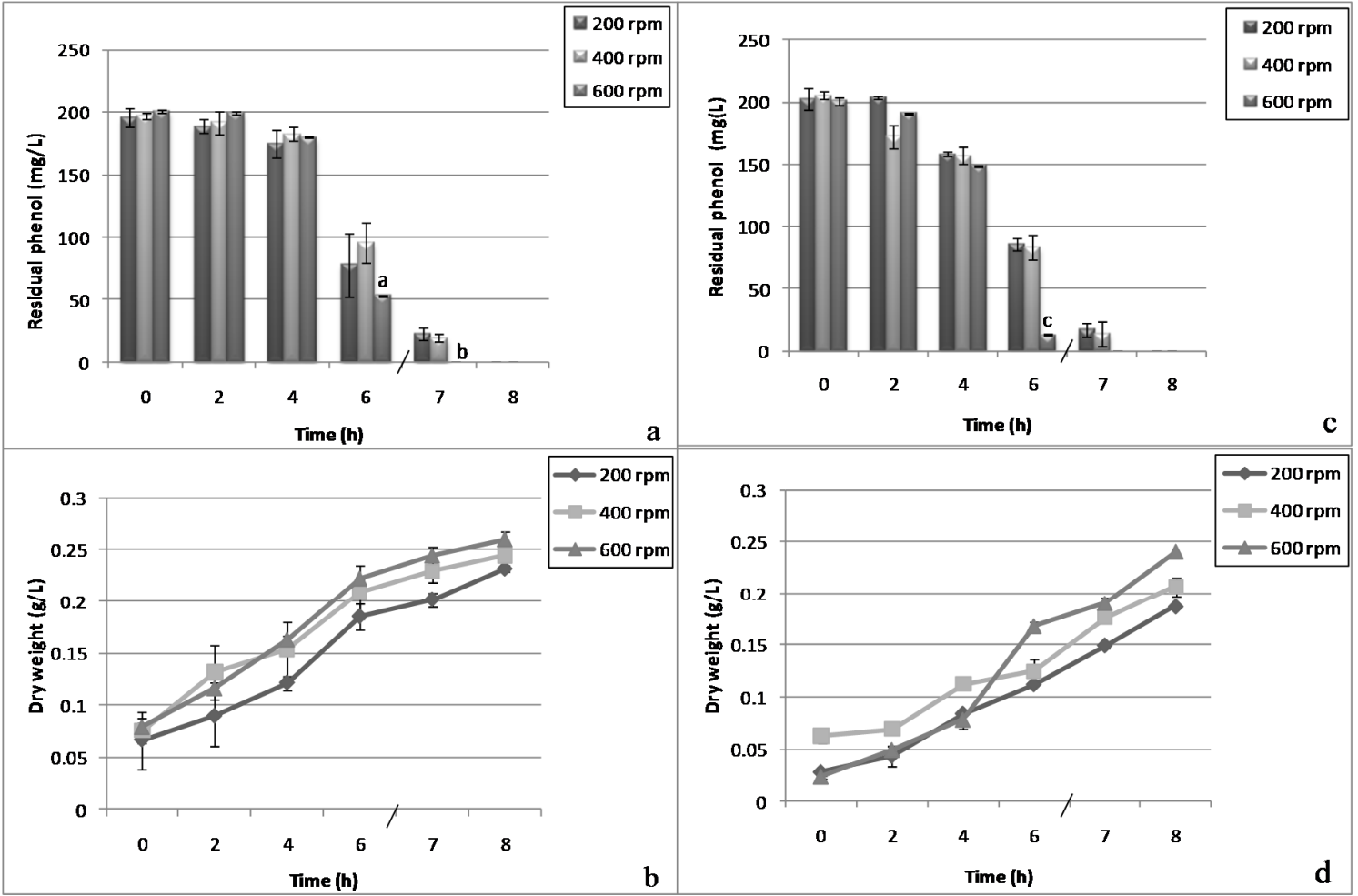

Figure 4 

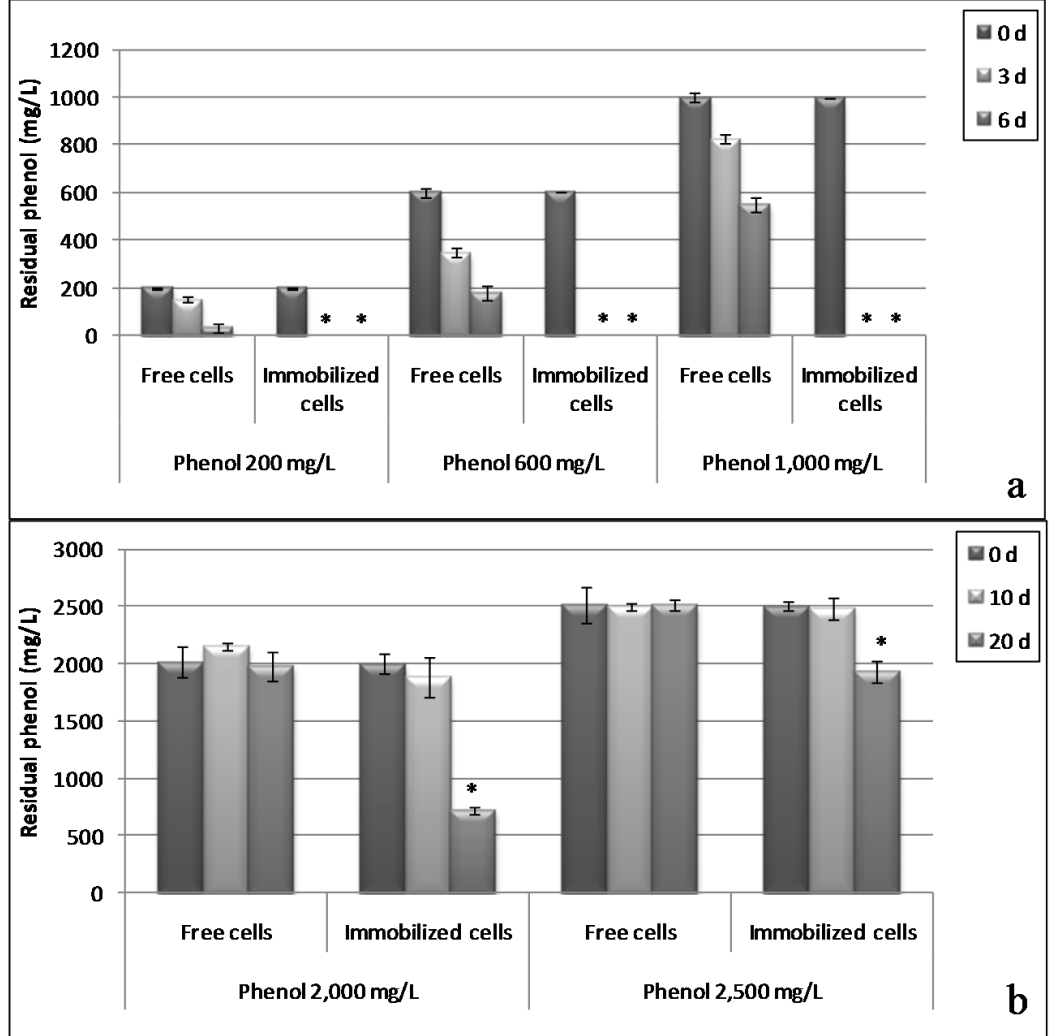

Figure 5 

end of phenol degradation experiments

66

67

\begin{tabular}{ccccc}
\hline \multirow{2}{*}{ Phenol } & \multicolumn{4}{c}{ Protein } \\
\cline { 2 - 5 } & Time & Beads $(\mathrm{mg} / \mathrm{g})$ & Reaction media $(\mathrm{mg} / \mathrm{mL})$ & Free cells $(\mathrm{mg} / \mathrm{mL})$ \\
\hline \multirow{2}{*}{200} & Initial value & $16 \pm 1$ & $0.05 \pm 0$ & $0.51 \pm 0.04$ \\
& Final value & $16 \pm 2$ & $0 \pm 0$ & $1.03 \pm 0.1^{*}$ \\
\hline \multirow{2}{*}{600} & Initial value & $18 \pm 6$ & $0.03 \pm 0.009$ & $0.56 \pm 0.007$ \\
& Final value & $22 \pm 4$ & $0.23 \pm 0.12$ & $2.33 \pm 0.1^{*}$ \\
\hline \multirow{2}{*}{1,000} & Initial value & $18 \pm 7$ & $0 \pm 0$ & $0.55 \pm 0.1$ \\
& Final value & $20 \pm 3$ & $0.18 \pm 0.007$ & $2.66 \pm 0.45^{*}$ \\
\hline \multirow{2}{*}{2,000} & Initial value & $17 \pm 5$ & $0.07 \pm 0.01$ & $0.49 \pm 0.06$ \\
& Final value & $20 \pm 2$ & $0.21 \pm 0.03$ & $1.9 \pm 0.34^{*}$ \\
\hline \multirow{2}{*}{2,500} & Initial value & $19 \pm 6$ & $0.06 \pm 0.009$ & $0.58 \pm 0.08$ \\
& Final value & $17 \pm 4$ & $0.20 \pm 0.09$ & $1.5 \pm 0.35^{*}$ \\
\hline
\end{tabular}




\begin{tabular}{|l|c|}
\hline Medium & $\mathrm{EC}_{50}(\%)$ \\
\hline MM & $>90$ \\
\hline MM plus phenol $(600 \mathrm{mg} / \mathrm{L})$ & $3.1^{*}$ \\
\hline PRS & $>90^{* *}$ \\
\hline
\end{tabular}

95

Ref. The values are the media of the three replicates of the assay.

* indicates significant differences $(p \leq 0.05)$ between the indicated value and MM 